\title{
Early infection in post-autologous hematopoietic stem cell transplant patients
}

\section{Princess Noorah Oncology Center experience}

Roaa S. Gassas, MSN, Abmed N. Absi, MD, Abdulrahman A. Alghamdi, MD, Abmed S. Alsaeed, MD,

Sameer M. Alamoudi, MD, Ihab Y. Hemaidi, MD, Majed D. Alahmadi, MD, Walaa A. Rajkhan, MD, Mannar M. Khalil, MD, Saleem K. Dadah, MD, Ahmed S. Higazi, MD, Amani S. Ahmed, MD.

\begin{abstract}

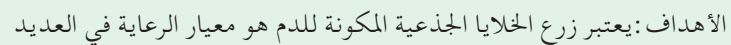

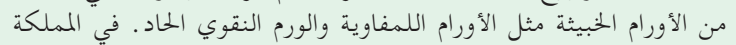

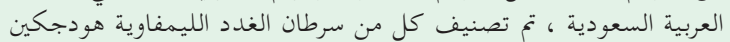

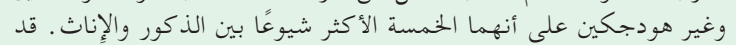

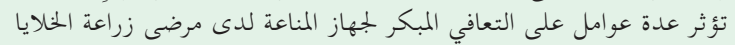

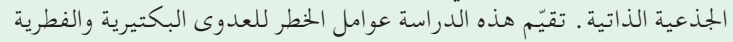

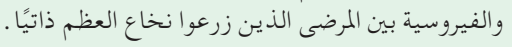

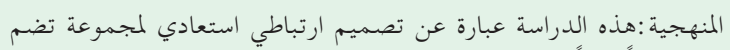

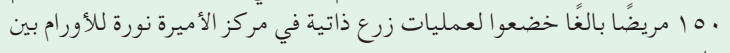

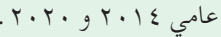

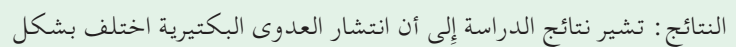

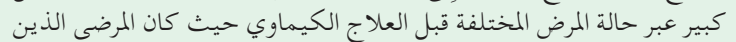

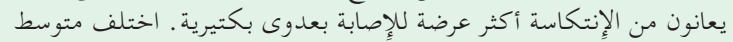

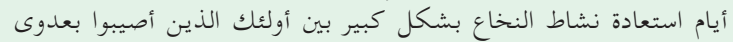

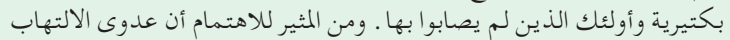

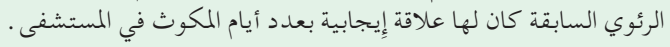

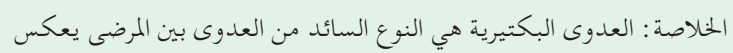

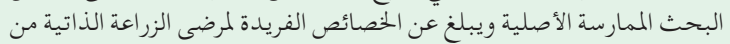

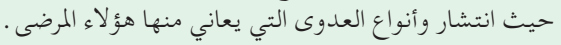

Objectives: To assess local epidemiology and risk factors for bacterial, fungal, and viral infections among the autologous bone marrow transplant population.

Methods: This study is a retrospective correlational cohort design comprising 150 adult patients who underwent autologous transplants at Princess Noorah Oncology Center, Jeddah, Saudi Arabia between 2014 and 2020.

Results: The study findings indicate that bacterial infection prevalence differed significantly across the different disease status pre-salvage as patients with the relapsed disease were more likely to have bacterial infections. The median of engraftment days differed significantly between those who had a bacterial infection and those who did not. Interestingly, previous pneumonia infection had a positive relationship with the number of hospital stays.

Conclusion: Bacterial infections are the dominant type of infection among the autologous patient population. The research reflects authentic practice and reports unique characteristics of autologous transplant patients in terms of the prevalence and types of infection these patients experience.

Keywords: bone marrow transplantation, lymphoma, infection, relapsed, myeloma

Saudi Med J 2021; Vol. 42 (8): 847-852 doi: 10.15537/smj.2021.42.8.20210236

From the Department of Adult Hematology Blood and Marrow Transplant (Gassas), King Abdulaziz Medical City, National Guard Health Affairs; and from the Adult Hematology Blood and Marrow Transplant Unit (Absi, Alghamdi, Alsaeed, Alamoudi, Hemaidi, Alahmadi, Rajkhan, Khalil, Dadah, Higazi, Ahmed), Princess Noorah Oncology Center, Jeddah, Kingdom of Saudi Arabia.

Received 25th March 2021. Accepted 27th June 2021.

Address correspondence and reprint request to: Ms. Roaa S. Gassas, Department of Adult Hematology Blood and Marrow Transplant, King Abdulaziz Medical City, National Guard Health Affairs, Jeddah, Kingdom of Saudi Arabia.E-mail: Roaa-sabri@hotmail.com ORCID ID: https://orcid.org/0000-0001-5222-213X

A utologous hematopoietic stem cell transplantation (ASCT) is considered the standard of care in relapsed/refractory lymphoid malignancies, multiple myeloma disease, and some solid tumors in children, such as neuroblastoma. Autologous hematopoietic stem cell transplantation represents $58 \%$ of all bone marrow transplants (BMT) in Europe (plasma cell disorders, 
46\%; non-Hodgkin's lymphoma [NHL], 30\%; Hodgkin's disease, 11\%). Autologous hematopoietic stem cell transplantation is also considered the gold standard for eligible patients diagnosed with myeloma. In spite of the introduction of several new regimens for myeloma, the transplant remains a major component of the therapeutic plan to prolong progression-free survival. ${ }^{1}$ In Saudi Arabia, both Hodgkin lymphoma (HL) and NHL were rated among the top 5 most frequent cancer types among males and females. ${ }^{2}$ Lymphomas and multiple myeloma accounted for $11.8 \%$ of deaths among the Saudi population in $2014 .{ }^{3}$ Complications are expected during and shortly after the transplant course. One major complication is the occurrence of infection, which is directly related to high doses of chemotherapy and the consequent major immunosuppression, breach of the mucous membrane barrier in the gastrointestinal tract, and line-related infections. Therefore, infection occurs in almost all patients due to a weakened immune system and prolonged neutropenia, and has been proven to be a major cause of mortality during therapy. Some factors that have been demonstrated to increase the risk of infection in transplant patients include conditioning regimen, disease status pretransplant, patient comorbidities, and associated immunodeficiencies. ${ }^{4}$ Data concerning the factors affecting early immune recovery in ASCT are limited. Although numerous factors are associated with early recovery, those factors are poorly recognized. Therefore, identification may enhance early immune recovery and will be helpful in improving the long-term outcome in these patients. ${ }^{5}$ The most common infection in posttransplant is bacterial, which can involve gram-positive or gram-negative bacteria, fungal or viral in nature. The transplant course centers around conditioning chemotherapy or high dose therapy. One major side effect of conditioning chemotherapy is bone marrow damage (neutropenia); therefore, collected stem cells are reinfused to help the patient recover and shorten the period of neutropenia and infection. Neutropenia in the pre-engraftment period, accompanied by the disruption of mucocutaneous barriers, is an important predisposing factor for infections that can lead to morbidity. ${ }^{6}$ Other contributing factors included age, disease status, lines of chemotherapy, number of CD34, engraftment, and duration of neutropenia.

Disclosure. Authors have no conflict of interests, and the work was not supported or funded by any drug company.
The aim of this study was to assess local epidemiology and risk factors for bacterial, fungal, and viral infections among the autologous BMT population. Due to the vulnerable immune system of those patients, establishing infectious data auditing on a local level is essential. Furthermore, the patients' related factors certainly do carry some local variation based on the relatively unique patients' local characteristics. Developing a reliable predictive measure for the occurrence of infections would be highly useful, along with identifying low-risk patients who could potentially be provided ASCT on an outpatient basis.

Methods. This study was a retrospective correlational cohort design. All cases were collected from Princess Noorah Oncology Center (PNOC), Jeddah, Saudi Arabia. The sample included all autologous BMT patients from March 2014 until June 2020. Purposive sampling, a type of nonprobability sampling, was used to collect 150 patients.

The inclusion criteria was autologous BMT patients who had transplant at PNOC. To ensure a representative sample and to achieve the study's goal, all transplanted patients were included in the study. The researcher collected the following data: gender; diagnosis (HL, NHL, and multiple myeloma); disease status; relapsed or refractory (no response to treatment or treatment resistance); number of lines salvage chemotherapy age; diabetes; previous fungal infection; CD34; engraftment; cytomegalovirus (CMV) status pre-BMT; neutropenic fever; pneumonia (neutropenic colitis - ileitis), bacterial infections (gram positive [GP] infections, gram negative (GN) infections Clostridium difficile [C. diff]); fungal infections Candida aspergillosis; fungal infections radiologic - cultures proven: viral infections, herpes simplex viruses (HSV), human alphaherpesvirusvaricella zoster virus, human immunodeficiency virus, respiratory syncytial virus influenza; and parasitic infections and parasites. All data were collected from patient records from day 0 (referred to as transplant day) until 30 days post-transplant. This time frame was selected because it represented the expected time for an infection to occur. ${ }^{7}$

Statistical analysis. The data were analyzed using IBM SPSS Statistics for Windows, version 25 (IBM Corp, Armonk, N.Y., USA), which included descriptive statistics as mean, median, and mode. A p-value $<0.05$ was considered statistically significant. To assess differences between categorical variables in the same population, the Chi-square and Fisher's exact tests were used. The Mann-Whitney $U$ test was also used to compare the means of engraftment, CD34 count, 
and length of stay in the hospital between infected and uninfected patients. All of the tests mentioned have been used based on the type of variable and whether or not it meets parametric assumptions. Participants' privacy and confidentiality were maintained through the anonymity of names and file numbers. International Review Board approval was obtained from the Institutional Review Board at the Ministry of National Guard Health Affairs.

Results. The data analysis included 150 patients, $50.7 \%$ were ages between 21 and 40,63.3\% males, and $86 \%$ did not have diabetes. In terms of diagnosis, $44 \%$ had HL with NHL, and multiple myeloma accounting for the remaining 51.4\%. Furthermore, 56 (37.7\%) patients had refractory disease, while 44 (29.3\%) patients relapsed. Before undergoing transplant, $47.3 \%$ of the patients received one line of salvage chemotherapy. In comparison, $14.7 \%$ of the sample received 2 lines of salvage chemotherapy (Table 1). Table 2 shows the prevalence of bacterial infections with $95 \%$ confidence intervals (CI).

In Table 1, 3 and 4, the findings indicate that bacterial infection (gram-positive and gram-negative) was the dominant type among the group (40\%). No viral infection was found among the sample. Only one parasitic infection was documented and was consequently excluded from the analysis. Furthermore, there was a significant correlation between the prevalence of bacterial infection and disease status prior to salvage $(p=0.034)$. There is a positive relationship between patients with relapsing disease and bacterial infections, $(p=0.06)$. Nonetheless, patients in the multiple myeloma group were less likely to have bacterial infections. Additionally, there was a strong association between patients with a history of linerelated infection and bacterial infections $(p<0.001)$. The median of engraftment days differed significantly among those who did or did not have a bacterial infection ( $U=2101.5, Z=2.5, p=0.013)$. Similarly, the median of time to discharge showed significant differences among those who did or did not have a bacterial infection ( $\mathrm{U}=1943.5, \mathrm{Z}=3.2, p=0.001)$. Additionally, median time to discharge varied among those who did or did not have pneumonia $(p=0.033)$.

Discussion. The study results revealed that overall infections were bacterial gram-positive and negative. Similar to other study findings which reported a higher finding of bacterial infections, representing $70 \%$ of the patients in that study. ${ }^{8}$ The non-existence of viral infection reflects improved pre-transplant serological clearance which include the followings tests (hepatitis,
Table 1 - Baseline characteristics of participants and their disease status.

\begin{tabular}{|c|c|c|}
\hline Variables & $\mathrm{n}$ & $(\%)$ \\
\hline \multicolumn{3}{|l|}{ Age } \\
\hline Up to 20 years & 15 & $(10.0)$ \\
\hline $21-40$ years & 76 & $(50.7)$ \\
\hline Above 40 years & 59 & $(39.3)$ \\
\hline Mean & 37.5 & \\
\hline SD & \pm 13.5 & \\
\hline Range & 54 & \\
\hline \multicolumn{3}{|l|}{ Gender } \\
\hline Male & 95 & $(63.3)$ \\
\hline Female & 55 & $(36.7)$ \\
\hline \multicolumn{3}{|l|}{ Diabetes mellitus } \\
\hline Yes & 21 & $(14.0)$ \\
\hline No & 129 & (86.0) \\
\hline \multicolumn{3}{|l|}{ Diagnosis } \\
\hline $\mathrm{HL}$ & 66 & $(44.0)$ \\
\hline NHL & 37 & (24.7) \\
\hline $\mathrm{MM}$ & 40 & (26.7) \\
\hline Pomes syndrome & 3 & $(2.0)$ \\
\hline APL & 3 & $(2.0)$ \\
\hline Germ cell tumor & 1 & $(0.7)$ \\
\hline \multicolumn{3}{|c|}{$\begin{array}{l}\text { Disease status pre-salvage for } H L \\
\text { and NHL }\end{array}$} \\
\hline Relapsed & 44 & (29.3) \\
\hline Refractory & 56 & (37.3) \\
\hline NA & 50 & (33.3) \\
\hline \multicolumn{3}{|c|}{$\begin{array}{l}\text { Number of lines (salvage } \\
\text { chemotherapy) }\end{array}$} \\
\hline One line & 71 & $(47.3)$ \\
\hline Two lines & 22 & (14.7) \\
\hline Three lines & 9 & $(6.0)$ \\
\hline Four lines & 1 & $(0.7)$ \\
\hline NA & 47 & (31.3) \\
\hline \multicolumn{3}{|c|}{$\begin{array}{l}\text { SD: standard deviation, HL: Hodgkin lymphoma, } \\
\text { NHL: non-Hodgkin lymphoma, MM: multiple } \\
\text { myeloma, APL: acute promyelocytic leukemia, NA: not } \\
\text { applicable (multiple myeloma group) }\end{array}$} \\
\hline
\end{tabular}

Table 2 - Prevalence of bacterial infections with $95 \%$ confidence interval (CI).

\begin{tabular}{lc}
\hline Infection & Prevalence $(\mathbf{9 5} \% \mathrm{CI})$ \\
\hline Neutropenic fever & $98.7(96.7-100)$ \\
Neutropenic colitis/ileitis & $7.3(3.3-12)$ \\
Pneumonia & $3.3(0.7-6.7)$ \\
Gram positive infection & $12.7(7.4-18)$ \\
Gram negative infection & $30(22.7-37.3)$ \\
Clostridium difficile & $9.3(5.3-14.7)$ \\
\hline
\end{tabular}

human immunodeficiency virus, syphilis, toxoplasmosis, varicella zoster, CMV, EBV, HSV, HTLV1/11, and brucella), plus the utilization of prophylactic antiviral therapy. This result indicates that viral infection is less common among the autologous population. However, 
Table 3 - Univariate analysis for baseline and disease characteristics and infectious complications in patients who underwent autologous hematopoietic stem cell transplant modified.

\begin{tabular}{|c|c|c|c|c|c|c|}
\hline \multirow[b]{2}{*}{ Characteristic } & \multicolumn{2}{|c|}{ Neutropenic fever } & \multirow[b]{2}{*}{$P$-value } & \multicolumn{2}{|c|}{ Neutropenic colitis/ileitis } & \multirow[b]{2}{*}{$P$-value } \\
\hline & $\begin{array}{c}\text { Yes } \\
\text { n (\%) }\end{array}$ & $\begin{array}{c}\text { No } \\
\text { n (\%) }\end{array}$ & & $\begin{array}{c}\text { Yes } \\
\text { n (\%) }\end{array}$ & $\begin{array}{c}\text { No } \\
\text { n }(\%) \\
\end{array}$ & \\
\hline \multicolumn{7}{|l|}{ Gender } \\
\hline Male & $93(97.9)$ & $2(2.1)$ & \multirow{2}{*}{$0.532^{*}$} & $5(5.3)$ & $90(94.7)$ & \multirow{2}{*}{$0.212^{*}$} \\
\hline Female & $55(100.0)$ & $0(0)$ & & $6(10.9)$ & $49(89.1)$ & \\
\hline \multicolumn{7}{|l|}{ Age category } \\
\hline Up to 20 years & $15(100.0)$ & $0(0)$ & \multirow{3}{*}{$0.344^{*}$} & $1(6.7)$ & $14(93.3)$ & \multirow{3}{*}{$0.900^{*}$} \\
\hline $21-40$ years & $76(100.0)$ & $0(0)$ & & $5(6.6)$ & $71(93.4)$ & \\
\hline 41 years and above & $57(96.6)$ & $2(3.4)$ & & $5(8.5)$ & $54(91.5)$ & \\
\hline \multicolumn{7}{|l|}{ Diabetes mellitus } \\
\hline Yes & $21(100.0)$ & $0(0)$ & \multirow{2}{*}{$0.999^{*}$} & $0(0)$ & $21(100.0)$ & \multirow{2}{*}{$0.364^{*}$} \\
\hline No & $127(98.4)$ & $2(1.6)$ & & $11(8.5)$ & $118(91.5)$ & \\
\hline \multicolumn{7}{|l|}{ Patient diagnosis } \\
\hline $\mathrm{HL}$ & $66(100.0)$ & $0(0)$ & \multirow{6}{*}{$0.221^{*}$} & $5(7.6)$ & $61(92.4)$ & \multirow{6}{*}{$0.548^{*}$} \\
\hline NHL & $37(100.0)$ & $0(0)$ & & $4(10.8)$ & $33(89.2)$ & \\
\hline MM & $38(95.0)$ & $2(5.0)$ & & $2(5)$ & $38(95.0)$ & \\
\hline Pomes syndrome & $3(100) .0$ & $0(0)$ & & $0(0)$ & $3(100)$ & \\
\hline APL & $3(100.0)$ & $0(0)$ & & $0(0)$ & $3(100)$ & \\
\hline Germ cell tumor & $1(100.0)$ & $0(0)$ & & $0(0)$ & $1(100)$ & \\
\hline \multicolumn{7}{|c|}{$\begin{array}{l}\text { Disease status pre-salvage for } H L \\
\text { and } N H L\end{array}$} \\
\hline Relapsed & $44(100)$ & $0(0)$ & \multirow{3}{*}{$0.194^{*}$} & $1(2.3)$ & $43(97.7)$ & \multirow{3}{*}{$0.066^{*}$} \\
\hline Refractory & $56(100.0)$ & $0(0)$ & & $8(14.3)$ & $48(85.7)$ & \\
\hline NA & $48(96.0)$ & $2(4.0)$ & & $2(4.0)$ & $48(96.0)$ & \\
\hline \multicolumn{7}{|c|}{$\begin{array}{l}\text { Number of lines (salvage } \\
\text { chemotherapy) }\end{array}$} \\
\hline One line & $71(100.0)$ & $0(0)$ & \multirow{5}{*}{$0.339^{*}$} & $5(7)$ & $66(93.0)$ & \multirow{5}{*}{$0.458^{*}$} \\
\hline Two lines & $22(100.0)$ & $0(0)$ & & $3(13.6)$ & $19(86.4)$ & \\
\hline Three lines & $9(100.0)$ & $0(0)$ & & $1(11.1)$ & $8(88.9)$ & \\
\hline Four lines & $1(100.0)$ & $0(0)$ & & $0(0)$ & $1(100)$ & \\
\hline NA & $45(95.7)$ & $2(4.3)$ & & $2(4.3)$ & $45(95.7)$ & \\
\hline \multicolumn{7}{|l|}{ ICU admission } \\
\hline Yes & $3(100.0)$ & $0(0)$ & \multirow{2}{*}{$0.999^{*}$} & $0(0)$ & $3(100.0)$ & $0999 *$ \\
\hline No & $145(98.6)$ & $2(1.4)$ & & $11(7.5)$ & $136(92.5)$ & 0.999 \\
\hline Line-related infection & & & & & & \\
\hline Yes & $12(100)$ & $0(0)$ & & $0(0)$ & $12(100.0)$ & \\
\hline $\mathrm{NO}$ & $136(98.6)$ & $2(1.4)$ & $0.999^{*}$ & $11(8.0)$ & $127(92)$ & $0.601^{*}$ \\
\hline CD34 & & & & & & \\
\hline Median (range) & $4.54(30.61)$ & $8.94(6.76)$ & 0.159 & $3.92(8.5)$ & $90(94.7)$ & 0.091 \\
\hline Engraftment & & & & & & \\
\hline Median (range) & $10(19.0)$ & $10.50(1.0)$ & 0.650 & $9(2.0)$ & $49(89.1)$ & 0.157 \\
\hline Discharge & & & & & & \\
\hline Median (range) & $14(46.0)$ & $12.50(1.0)$ & 0.206 & $13(16.0)$ & $14(93.3)$ & 0.988 \\
\hline
\end{tabular}

disease-related factors such as the presence of relapsed disease correlated with a higher risk of infection, which probably reflects the number of salvage chemotherapy lines the patients might have received that deepened their immunesuppression. The finding is related to the reports by Valtola et $\mathrm{al}^{9}$ and Lakatos et $\mathrm{al},{ }^{5}$ who noted that relapsed disease was a factor affecting early recovery. On the other hand, in our study, the multiple myeloma group had a lower risk of infection, which is contrary to the results reported by Park et al, ${ }^{10}$ showing that the rate of infection was higher among patients with multiple myeloma. We hypothesized that this outcome could be a reflection of better patient selection plus the utilization of more novel induction therapies in myeloma patients prior to transplant. We found that line infection is associated with bacteria. Ali et $\mathrm{a}^{11}$ 
Table 4 - Univariate analysis for baseline and disease characteristics and infectious complications in patients who underwent autologous hematopoietic stem cell transplant modified.

\begin{tabular}{|c|c|c|c|c|c|c|}
\hline \multirow{3}{*}{ Characteristics } & \multicolumn{2}{|c|}{ Pneumonia } & \multicolumn{4}{|c|}{ Bacterial } \\
\hline & Yes & No & $P$-value & Yes & No & $P$-value \\
\hline & n (\%) & n (\%) & & n (\%) & n (\%) & \\
\hline \multicolumn{7}{|l|}{ Gender } \\
\hline Male & $3(3.2)$ & $92(96.8)$ & \multirow{2}{*}{$0.999^{*}$} & $42(44.2)$ & $53(55.8)$ & \multirow{2}{*}{0.732} \\
\hline Female & $2(3.6)$ & $53(96.4)$ & & $22(40.0)$ & $33(60.0)$ & \\
\hline \multicolumn{7}{|l|}{ Age category (years) } \\
\hline Up to 20 & $1(6.7)$ & $14(93.3)$ & \multirow{3}{*}{$0.162^{*}$} & $6(40.0)$ & $9(60.0)$ & \multirow{3}{*}{0.971} \\
\hline $21-40$ & $4(5.3)$ & $72(94.7)$ & & $32(42.1)$ & $44(57.9)$ & \\
\hline$\geq 41$ & $0(0)$ & $59(100)$ & & $26(44.1)$ & $33(55.9)$ & \\
\hline \multicolumn{7}{|l|}{ Diabetes mellitus } \\
\hline Yes & $0(0)$ & $21(100)$ & \multirow[b]{2}{*}{$0.999^{*}$} & $11(52.4)$ & $10(47.6)$ & \multirow[b]{2}{*}{0.351} \\
\hline No & $5(3.9)$ & $124(96.1)$ & & $53(41.1)$ & $76(58.9)$ & \\
\hline \multicolumn{7}{|l|}{ Patient diagnosis } \\
\hline HL & $2(3)$ & $64(97.0)$ & \multirow{6}{*}{$0.309^{*}$} & $27(40.9)$ & $39(59.1)$ & \multirow{6}{*}{$0.223^{*}$} \\
\hline NHL & $3(8.1)$ & 34 (91.9) & & $21(56.8)$ & $16(43.2)$ & \\
\hline $\mathrm{MM}$ & $0(0)$ & $40(100.0)$ & & $13(32.5)$ & $27(67.5)$ & \\
\hline Pomes syndrome & $0(0)$ & $3(100.0)$ & & $1(33.3)$ & $2(66.7)$ & \\
\hline APL & $0(0)$ & $3(100.0)$ & & $1(33.3)$ & $2(66.7)$ & \\
\hline Germ cell tumor & $0(0)$ & $1(100.0)$ & & $1(100.0)$ & $0(0)$ & \\
\hline \multicolumn{7}{|c|}{$\begin{array}{l}\text { Disease status pre-salvage for } H L \\
\text { and } N H L\end{array}$} \\
\hline Relapsed & $1(2.3)$ & $43(97.7)$ & \multirow{3}{*}{$0.627^{*}$} & $25(56.8)$ & $19(43.2)$ & \multirow{3}{*}{0.034} \\
\hline Refractory & $3(5.4)$ & 53 (94.6) & & $24(42.9)$ & $32(57.1)$ & \\
\hline NA & $1(2.0)$ & $49(98.0)$ & & $15(30.0)$ & $35(70)$ & \\
\hline \multicolumn{7}{|c|}{$\begin{array}{l}\text { Number of lines (salvage } \\
\text { chemotherapy) }\end{array}$} \\
\hline One line & $3(4.2)$ & $68(95.8)$ & \multirow{5}{*}{$0.896^{*}$} & $33(46.5)$ & $38(53.5)$ & \multirow{5}{*}{0.291} \\
\hline Two lines & $1(4.5)$ & $21(95.5)$ & & $10(45.5)$ & $12(54.5)$ & \\
\hline Three lines & $0(0)$ & $9(100.0)$ & & $5(55.6)$ & $4(44.4)$ & \\
\hline Four lines & $0(0)$ & $1(100.0)$ & & $1(100.0)$ & $0(0)$ & \\
\hline NA & $1(2.1)$ & $46(97.9)$ & & $15(31.9)$ & $32(68.1)$ & \\
\hline \multicolumn{7}{|l|}{ ICU admission } \\
\hline Yes & $0(0)$ & $3(100.0)$ & \multirow{2}{*}{$0.999^{*}$} & $2(66.7)$ & $1(33.3)$ & \multirow{2}{*}{$0.576^{*}$} \\
\hline No & $5(3.4)$ & $142(96.6)$ & & $62(42.2)$ & $85(57.8)$ & \\
\hline \multicolumn{7}{|c|}{ Line-related infection } \\
\hline Yes & $0(0)$ & $12(100)$ & & $12(100)$ & $0(0)$ & $<0001$ \\
\hline NO & $5(3.6)$ & $133(96.4)$ & $0.999^{*}$ & $52(37.7)$ & $86(62.3)$ & $<0.001$ \\
\hline$C D 34$ & & & & & & \\
\hline Median (range) & $3.83(3.76)$ & $14(46.0)$ & 0.429 & $4.72(12.1)$ & $4.47(30.61)$ & 0.917 \\
\hline Engraftment & & & & & & \\
\hline Median (range) & $10(4.0)$ & $4.61(30.6)$ & 0.515 & $10(15.0)$ & $10.50(11.0)$ & 0.001 \\
\hline Discharge & & & & & & \\
\hline Median (range) & $16(6.0)$ & $10(19.0)$ & 0.033 & $15(46.0)$ & $13(13.0)$ & 0.013 \\
\hline
\end{tabular}

concluded that bacterial infection was present in 18 out of 108 patients. The number of patients with C. diff was minor, 14 patients (almost 9\%). This finding concurs with what is already known on $C$. diff and uncommon among the autologous group and is supported by Rahman et a ${ }^{12}$ reported 8 cases who became infected post-transplant.
Almost all patients experienced neutropenic fever pre-engraftment, which is consistent with the findings of 2 studies. ${ }^{13,14}$ In both studies, the vast majority of patients had neutropenic fever. The results highlighted that infection had affected engraftment. However, according to Hassan, ${ }^{15}$ multiple factors may affect engraftment. For example, neutrophil engraftment was 
affected by weight, stage of disease at diagnosis, number of previous chemotherapy cycles, and pre-transplant radiotherapy. In contrast, platelet engraftment was shown to be affected by the same factors in addition to CD34 dosage and stage of the disease. Our study found no relationship between CD34 infused and engraftment. This result differs from Nath, ${ }^{16}$ who asserted that higher dose of CD34+ stem cells was linked to faster neutrophil recovery and engraftment. This outcome could be explained by the earlier use of hematopoietic growth factors and improved supportive and prophylactic antibiotics, which can overcome such a difference. Park et $\mathrm{al}^{10}$ revealed that hospital stays were longer in patients who experienced bacterial infection, which is identical to our findings. In contrast, Moghnieh et $\mathrm{al}^{8}$ found that a patient's average stay was not affected by infection.

Study limitations. The study was retrospective and involved a limited number of patients. However, the research reflects authentic practice and has reported unique characteristics of autologous transplant patients in terms of the prevalence of bacterial infection and prevalence of viral and fungal infections.

We began the auto-SCT program at PNOC in 2014 as an in-patient setting. Many centers around the world have shifted such procedures to an out-patient setting. The occurrence of infections, particularly bacterial infections, is a major impediment to such shifting. The findings of this study could be used to screen patients for out-patient auto-SCT in Saudi Arabia.

In conclusion, the study findings showed that bacterial infections are the most common in autologous patients, especially gram-negative infection. Thus, increasing the awareness of local epidemiology data is essential. A multicenter study on a national level is highly recommended. In addition, the inclusion of allogeneic transplant patients could yield helpful information for the medical professionals who are treating these patients.

Acknowledgment. The authors gratefully acknowledge Cambridge Proofreading LLC for the English language editing.

\section{References}

1. Hübel K, de la Rubia J, Azar N, Corradini P. Current status of haematopoietic autologous stem cell transplantation in lymphoid malignancies: a European perspective. Eur $J$ of Haematol 2015; 94: 12-22.

2. World Health Organization, International Agency for Research on Cancer, Saudi Arabia. The Global Cancer Observatory. [Updated 2021; accessed January 2021]. Available from: https://gco.iarc.fr/today/data/factsheets/populations/682saudi-arabia-fact-sheets.pdf
3. World Health Organization. Cancer Country Profile. [Updated 2014; accessed January 2021]. Available from: https://www. who.int/cancer/country-profiles/chn_en.pdf

4. Gil L, Styczynski J, Komarnicki M. Infectious complication in 314 patients after high-dose therapy and autologous hematopoietic stem cell transplantation: risk factors analysis and outcome. Infection 2007; 35: 421-427.

5. Lakatos B, Szabó H, Csordás K, Tatai G, Nikolova R, Csomor J, Sinkó J. Epidemiology of early infections after autologous hematopoietic stem cell transplantation. Analysis of data from 699 patients treated in a Hungarian centre. Orv Hetil 2020; 161: 103.

6. Girmenia C, Bertaina A, Piciocchi A, Perruccio K, Algarotti A, Busca A, et al. Incidence, risk factors and outcome of preengraftment gram-negative bacteremia after allogeneic and autologous hematopoietic stem cell transplantation: an Italian prospective multicenter survey. Clin Infect Dis 2017; 65: 1884-1896.

7. Satlin MJ, Vardhana S, Soave R, Shore TB, Mark TM, Jacobs $\mathrm{SE}$, et al. Impact of prophylactic levofloxacin on rates of bloodstream infection and fever in neutropenic patients with multiple myeloma undergoing autologous hematopoietic stem cell transplantation. Biol Blood Marrow Transplant 2015; 21 : 1808-1814.

8. Moghnieh R, Abdallah D, Awad L, Jisr T, Mugharbil A, Youssef A, et al. Bacteraemia post-autologous haematopoietic stem cell transplantation in the absence of antibacterial prophylaxis: a decade's experience from Lebanon. Infection 2018; 46: 823-835.

9. Valtola J, Varmavuo V, Ropponen A, Selander T, Kuittinen O, Kuitunen H, et al. Early immune recovery after autologous transplantation in non-Hodgkin lymphoma patients: predictive factors and clinical significance. Leuk Lymphoma 2016; 57 : 2025-2032.

10. Park H, Youk J, Kim HR, Koh Y, Kwon JH, Yoon SS, et al. Infectious complications in multiple myeloma receiving autologous stem cell transplantation in the past 10 years. Int J Hematol 2017; 106: 801-810.

11. Ali N, Adil SN, Shaikh MU. Bloodstream and central line isolates from hematopoietic stem cell transplant recipients: data from a developing country. Transpl Infect Dis 2014; 16: 98-105.

12. Rahman S, Rybicki L, Ky Hamilton B, Pohlman B, Jagadeesh D, Cober E, et al. Early infectious complications after autologous hematopoietic cell transplantation for multiple myeloma. Transpl Infect Dis 2019; 21: e13114.

13. Srinivasan A, McLaughlin L, Wang C, Srivastava DK, Shook DR, Leung W, et al. Early infections after autologous hematopoietic stem cell transplantation in children and adolescents: the St. Jude experience. Transpl Infec Dis 2014; 16: 90-97.

14. Averbuch D, Tridello G, Hoek J, Mikulska M, Akan H, Yaňez San Segundo L, et al. Antimicrobial resistance in gramnegative rods causing bacteremia in hematopoietic stem cell transplant recipients: intercontinental prospective study of the infectious diseases working party of the European bone marrow transplantation group. Clin Infect Dis 2017; 65: 1819-1828.

15. Hassan MN, Fauzi HM, Husin A, Mustaffa R, Hassan R, Ibrahim MI, et al. Autologous peripheral blood stem cell transplantation among lymphoproliferative disease patients: factors influencing engraftment. Oman Med J 2019; 34: 34-43.

16. Nath K, Boles R, McCutchan A, Vangaveti V, Birchley A, Irving I. The relationship between CD34+ stem cell dose and time to neutrophil recovery in autologous haematopoietic stem cell recipients-A single centre experience. Transfus Apher Sci 2018; 57: 532-536. 